allow for younger companies (one to three years) with capital of between CHF6 million and 10 million to go public, according to spokesperson, Leo Hug. Genescan (Freiburg, Germany), Arpida, and Actelion are IPO candidates in 2000, 2001, and before 2005, respectively. And NMT itself is planning to go public in four or five years.
There is, however, a lack of pre-seed money in the BioValley, according to Bruno Dalle Carbonare, head of the BioValley Platform (Basel). But Stefan Ryser, CEO at International Biomedicine Management Partners (Basel), says this funding gap could turn out to be an advantage for the BioValley. "In Germany, there is too much money from the state," he says, "German biomanagement teams do not have to strive hard to sell themselves. [But] in the Swiss BioValley region, companies will have more aggressive management teams similar to their US counterparts, and as a consequence they will be more competitive than the German firms."

Ingeborg Fürst

\title{
"GM-free" food labels are value-free
}

A consortium of seven European supermarkets, led by J Sainsbury (London), announced in March that its own-brand food products will not include any genetically modified (GM) ingredients. However, there are no scientific tests available that can substantiate such claims and the European Parliament has yet to define GM-free foodleaving the consortium's announcement little more than a publicity stunt.

The European Commission (EC; Brussels) is currently in discussions with the 15 member states to set an upper limit on the amount of GM ingredients permissible in food labeled GM-free (e.g., alcohol-free food is considered less than $0.05 \%$ alcohol by volume). At this stage there are no indications of what the limit will be and when it will come into force. When the issue of labeling GM food was addressed in mid-1998 by the EC, the European Union member states specified that food containing GM ingredients should be labeled (Nat Biotechnol. 16, 605, 1996), but made no policy regarding GM-free food, says Jochem Kubosch, an EC spokesperson on both industry and the novel foods act, under which the GM foods labeling rules are applied.

This leaves the supermarket consortium-also consisting of Marks \& Spencer (London), Carrefour (Paris), Effelunga (Rome), Migros (Basel), Delhaize (Brussels), and Superquinn (Dublin) - able only to volunteer "GM-free" labels.

But even Law Laboratories (Great Barr, UK), which is advising Sainsbury's on how to trace ingredients to source and certify that they are GM free, does not believe that GMfree claims are realistic. "We would not endorse the term 'genetically modified free.' But [would] say 'reasonable steps have been taken to ensure food contains no genetically modified ingredients," says Liz Paterson, sales and marketing executive at Law Laboratories.

Indeed, the consortium can make no firmer commitment than this, as there are no tests available to ensure that food is GM free. One of the world's leading GM food testing companies is Genetic ID (Fairfield, IA). According to John McCullough, the operations manager, Genetic ID uses specif- ic primers to detect DNA sequences derived from GM crops. Following PCR amplification, a quantitative figure is calculated of how much DNA from GM crops is present, and what percentage of the sample contains GM crops.

However, says McCullough, "the one Achilles heel is that [the test] needs coherent

It is impossible to make GMfree claims from testing. "You can claim 'nil detected,' but that doesn't mean there's nothing there."

DNA," and the smallest fragment the test can detect is around 200 nucleotides. Because fragment size is proportional to the amount of food processing that has taken place, the test is useless for highly processed foods such as soup or pizza. And the negligible amounts of DNA in refined oils, which are used in the preparation of innumerable food products, pose even more of a problem. "Even if you could detect the presence of genetically modified DNA [in oil], it would be very hard to quantify," says McCullough.

RHM Technology (High Wycombe, UK), which announced a new PCR-based test at the end of March, can detect DNA sequences as short as 100 base pairs. This test gives quantitative figures for Round-up Ready Soya and Bt 176 maize, and can detect the presence of DNA in 10 p.p.b. in oil, which is not possible with Genetic ID's test. But other approved GM produce such as tomatoes can only be detected qualitatively.

It is impossible to make GM-free claims from testing. "You can claim 'nil detected,' but that doesn't mean there's nothing there," according to John McDougall, a crop protection analyst at Wood Mackenzie (Edinburgh, UK). This is supported by Kubosch, "it is not possible at the moment" for someone to have a European stamp of approval on a claim that food is GM-free. Sainsbury's declined to comment.
A similar scenario was seen in 1995 when US dairy farmers tried to claim that the milk they produced did not involve the use of Monsanto's (St. Louis, MO) bovine somatotropin (BST) growth hormone (Bio/Technology 13, 13, 1995). The US Food and Drug Administration (Rockville, MD) allowed farmers to make BST-free claims, providing they were able to prove them to be true. However, the only tests available measured the levels of $\operatorname{IgF} 1$, which is elevated in the milk of cows receiving BST. But because IgF1 is also found in milk from cows not receiving BST, and is naturally elevated in cows for nine weeks after giving birth, it was impossible for the dairy farmers to prove that their milk was from BST-free cows.

Meanwhile, until official legislation is passed, if "GM-free" is shown voluntarily on a label, it falls under the jurisdiction of the EU Labeling Directive, the only "regulator" in the matter. The directive states that if a food is labeled GM-free it must contain no GM ingredients.

Within the UK, the Ministry of Agriculture Fisheries and Food (MAFF) is responsible for overseeing the implementation of the labeling directive. According to Nick Tomlinson, a MAFF spokesperson, if claims of GM-free are made on a food label, the procedures would be similar to those followed when peanut-free claims are made. This involves taking samples for testing in government-approved laboratories to ensure the truth of the claims. However, at this stage no formal procedure is in place for GM-free food. Until the upper limit is set, he says, detection of the presence of any GM material would breach the labeling directive.

According to Kubosch, supermarkets claiming GM-free food that is later found to be contaminated face "legal action," possibly fines, which would be forced by individual member states. But a greater deterrent, he thinks, would be the backlash from consumers angry at having been conned.

And the problem looks as if it's poised to continue. McDougall notes that, while there are only a few GM food ingredients now, "in 10 years there may be 40 ."

Adam Michael 